\title{
Pelaksanaan Pendidikan Agama pada Sekolah-sekolah di Kodia Malang
}

Moh. Kasiram

Direktur Program Pascasarjana STAIN Malang.

\section{ABSTRACT}

Religious educsion is one of the more imponeont element in adbieving tbe gaal of National Education in Indonesia. UUSPNNa211989 and GBBN 1993 Stated that

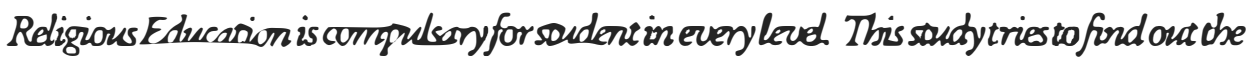
implemerecion of religious educarion in Kadia Malang. It is fornd ous that 1. religious readhers arevery serious in preparing tbe lesson; 2. tbeteadxers usenew methads in ceading religious ie: experioners and problem solving.

Menurut penjelasan pasal 29 ayat 2 UUSPN, bahwa pendidikan agama menupakan usaha untuk memperkuat iman dan ketaqwaan terhadap Tuhan Yang Maha Esa sesuai dengan agama yang dianut oleh peserta didik yang bersangkutan dengan memperhatikan tuntutan untuk menghormati agama lain dalam hubungan kerukunanantar umat beragama dalam masyarakat untuk mewrujudkan persatuan nasional. 
Permasalahan dalam penelitian ini berkisar pada: bagaimana strategi dan upaya guru pendidikan agama dalam melaksanakan pendidikan agama di sekolah dan bagaimana kondisi kontektual yang memberikan kekuatan pendorong axau penghambat pelaksanaan pendidikan agama. Tujuan penelitian ini ialah mendeskripsikan pelaksanaan pendidikan agama di sekolah dan mengidentifikasi faktor pendorang dan penghambatnya.

Penelitian ini mengambil sampel 6 sekolah yang terdiri dari 4 satuan pendidikan dasar dan 2 satuan pendidikan menengah, negeri dan swasta. Responden terdiri dari kepala sekolah, guru agama dan murid yang selunchmy berjumlah 436 orang. Metode pengumpulan data yang digunakan ialah: wawancara, observasi, angket dan dokumenter. Sedangkan metode analisisnya ialah analisis statistik dan deskriptif kualitatif.

Hasil temuan penelitian ini ialah: (1) Guru-guru agama telah menggunakan sarana yang dimiliki sekolah untuk kegiatan agama secara terprogram, (2) Semua guru telah mewajibkan siswanya untuk mengikuti kegiatan : pesantren kilat, PHBI shalat jamaah bergilir, dll. dengan memberi sanksi bagi yang tidak mengikuti. (3) Guru agama telah berusaha untuk menekankan P.BM-nya pada aspek afektif(sikap) dan ukuran keberhasilannya ialah perubahan tingkah laku murid di sekolah maupun di luar sekolah. (4) Pendekatan pembelajaran pendidikan agama menggunakan pendekatan pengalaman dan pembiasan dalam melaksanakan nilai-nilaiagama, (5) Guru agama telah memberikan materi penunjang yang tidak tercantum dalam kurikulum, (6) Metode yang digunakan adalah mewode ceramah, tanya jawab, drill, demonsrasidan kerja kelompok, (7) Media pembelajaran yang digunakan ialah media yang ada dan tidak terprogram, (8) Guru agama telah menjalin kerjasama dengan guru umum dalam kegiatan agama di sekolah maupun di luar sekolah (9) Kualitas rancangan pembelajaran (Satpel) umumnya sangat baik, (10) Kualitas kemampuan PBM juga sangat baik.

Faktor penunjang dalam pelaksanaan pendidikan agamaialah: (1) Sikap siswa antusias terhadap pelajaran agama, (2) Dapat diadakan berbagai kegjacan keagamaan di sekolah seperti : PHBI, BDI, pesantren kilat, latihan kader dasar muslim, shalat berjamaah, pengajian rutin, pondok romadlon, penambahan jam pelajaran, latihan khitabah, bakti sosial ke Panti Asuhan, (3) Dukungan 
kepala sekolah berupa : motivasi terhadap semua kegiatan keagamaan, selalu mendampingi setiap ada kegiatan agama, memberi fasilitas pendukung dan dukungan dana. Sedang faktor penghambatnya ialah: terbatasnya dana, sarana dan prasarana yang kurang memadai, siswa yang heterogen, keluarga siswa yang kurang mendukung, pengaruh media massa yang negatif dan variatif.

Kesimpulan yang dapat diambil ialah bahwa guru agama telah berusaha sedapat mungkin menjadikan pendidikan agama bisa berfungsi sebagai landasan dasar bagi pembentukan manusia Indonesia seutuhnya yang beriman dan bertaqwa terhadap Tuhan Yang Maha Esa. Saran yang dapat dikemukakan ialah pemanfaatan hasil penelitian ini dan penelitian lanjut.

\section{Pendahuluan}

Betapa pentingnya kedudukan pendidikan Agama dalam pembangunan manusia Indonesia seutuhnya, dapat dibuktikan dengan ditempatkannya unsur agama dalam sendi-sendi kehidupan berbangsa dan bernegara. Sila pertama dalam Pancasila adalah Sila Ketuhanan Yang Maha Esa, yang memberikan makna bahwa bangsa kita adalah bangsa yang beragama. Untuk membina bangsa yang beragama, pendidikan agama ditempatkan pada posisi strategis dan tak dapat dipisahkan dalam sistem pendidikan nasional kita.

Keterkaitan antara agama dengan sistem pendidikan nasional, jelas disebutkan dalam rumusan tujuan pendidikan nasional kita, baik dalam UUSPN No.2 tahun 1989 maupun dalam GBHN 1993. Dalam UUSPN disebutkan bahwa : "Pendidikan nasional bertujuan untuk mencerdaskan kehidupan bangsa dan mengembangkan manusia Indonesia seutuhnya, yaitu manusia yang beriman dan bertaqwa terhadap Tuhan Yang Maha Esa dan berbudi pekerti luhur, memiliki pengetahuan dan keterampilan, kesehatan jasmani dan rohani, kepribadian yang mantap dan mandiri serta rasa tanggung jawab kemasyarakatan dan kebangsaan," Sedangkan dalam GBHN 1993, disebutkan bahwa: Pendidikan Nasional bertujuan untuk meningkatkan kualitas manusia Indonesia, yaitu manusia yang beriman dan bertaqwa terhadap Tuhan Yang Maha Esa, berbudi luhur, berkepribadian, mandiri, maju, tangguh, cerdas, 
kreatif, terampil, berdisiplin, beretos kerja, profesional, tanggung jawab, dan produktif serta sehat jasmani dan rohani".

Kedua rumusan tujuan pendidikan nasional tersebut, diawali dengan sebutan manusia yang beriman dan bertaqwa terhadap Tuhan Yang Maha Esa. Begitu pentingnya unsur beriman dan bertaqwa terhadap Tuhan Yang Maha Esa ini, maka oleh GBHN dijadikan asas pertama dari asas-asas pembangunan nasional. Dengan asas beriman dan bertaqwa terhadap Tuhan Yang Maha Esa dimaksudkan, bahwa: "segala usaha dan kegiatan pembangunan nasional dijiwai, digerakkan, dan dikendalikan oleh keimanan dan ketaqwaan terhadap Tuhan Yang MahaEsa sebagai nilai luhur yang menjadi landasan spiritual, moral dan etik dalam rangka pembangunan nasional sebagai pengamalan Pancasila. Oleh karena itu GBHN memerintahkan agar: "diupayakan terus bertambah sarana yang diperlukan bagi pengembangan kehidupan beragama dan kepercayaan terhadap Tuhan Yang Maha Esa, termasuk sarana pendidikan agama pada semua jalur, jenis dan jenjang pendidikan termasuk prasekolah, yang pelaksanaannya sesuai dengan peraturan perundang-undangan yang berlaku". ${ }^{1}$

Untuk mewujudkan cita-cita ini, maka baik UUSPN No.2 Tahun 1989 maupun GBHN 1993 mewajibkan pendidikan agama dimasukkan kedalarn kurikulumsekolah. Pasal 39UUSPN ayat 2 menyebutkan, bahwa: isi kurikulum setiap jenis, jalur dan jenjang pendidikan wajib memuat: a) Pendidikan Pancasila, b) Pendidikan agama dan c) Pendidikan Kewarganegaraan. ${ }^{2} \mathrm{Hal}$ yang senada juga disebutkan dalam GBHN Bab IV bidang pendidikan, bahwa: "Kurikulum dan isi pendidikan yang memuat: pendidikan Pancasila, pendidikan agama dan pendidikan kewarganegaraən terus ditingkatkan dan dikembangkan di semua jalur, jenis dan jenjang pendidikan nasional". ${ }^{3}$

Dalam penjelasan pasal 39 ayat 2 UUSPN tersebut di atas, disebutkan bahwa pendidikan agama merupakan usaha untuk memperkuat iman dan ketaqwaanterhadap Tuhan Yang Maha Esa sesuai dengan agama yang dianut peserta didik yang bersangkutan dengan memperhatikan tuntutan untuk menghormati agama lain dalam hubungan kerukunan antar umat beragama dalammasyarakat untuk mewujudkan persatuan nasional. 
Keimanan dan ketaqwaan terhadap Tuhan Yang Maha Esa dapat berfungsi sebagai pengendali tingkah laku manusia. Dengan kokohnya iman dan taqwa, manusia bisa terhindar dari berbagai godaan nafsu pribadi yang negatif, jugadapat mendorong orang untuk berbuat kebaikan dan amal sholeh. Dengan demikian seorang yang beriman dan bertaqwa akan selalu dituntun oleh petunjuk Tuhan dalam kehidupan mereka sehari-hari. Dia dapat membedakan mana yang baik dan mana yang kurang baik, kemudian dapat bersikap tegas untuk memilih mana yang boleh dilakukan dan mana yang tidak boleh dilakukan. Dengan demikian dia tidak mudah terombang-ambing oleh pengaruh globalisasi yang makin mencekam.

Arus globalisasi ternyata semakin kompleks dan semakin intensif pengaruhnya dalam kehidupan manusia. Ini akibat dari berkembangnya mass media yang menyebarluaskan informasi budaya dengan cepat sehingga budaya tidak lagi bersifat lokal, akan tetapi bersifat nasional dan internasional. Hal ini akan meningkatkan hẹterogenitas nilai budaya dalam masyarakat, sehingga nilai agama yang semula menjadi satu-satunya sumber kebenaran, kini bisa menjadi kabur, bahkan bisa luntur. Kondisi ini akan sangat rawan bagi pendidikan dasar dan menengah. Ini merupakan tantangan bagi pendidikan agama, bagaimana agar secara fungsional pendidikan agama dapat menjawab berbagai persoalan yang dihadapi peserta didik di era globalisasi sekarang ini.

Untuk menghadapi tantangan ini, pendidik agama harus mampu mencari model penyampaian pendidikan agama yang baru, yang bisa memotivasi anak didik untuk secara aktif menjawab persoalan-persoalan kehidupan sehari-hari. Oleh karena itu, model pengajaran yang bersifat indoktrinasi dogmatis dan normatif, sudahtidak cocok lagi untuk digunakan. Pendidikan agama harus disampaikan secara empirik problematis, sehingga secara akfif anak didik dapat mengintegrasikan ajaran-ajaran agama dengan problem-problem sosial yang dihadapinya. Hal ini penting dalam pembentukan sikap sosial anak, dimana anak dilatih untuk menggunakan persepsi agamis terhadap realitas kehidupan. Disini guru agama harus selalu berusaha mengajak anak didik untuk melakukan refleksi teologis dalam menghadapi setiap bentuk tantangan hidup. Dengan demikian kehidupan 
anak didik sehari-hari tidak sampai terjadi hampa iman dan taqwa, sehingga bisa terhindar dari rasa tergantung pada orang lain (guru agama atau kyai) secara berlebihan. Secara perlahan akan terjadi internalisasi norma-norma agama kedalam diri anak didik, sehingga dalam melakukan setiap kegiatan tidak lagi karena takut pada guru atau orang lain, akan tetapi karena terpanggil oleh iman dan taqwanya terhadap Tuhan Yang Maha Esa.

Disamping pendidikan agama disampaikan secara emperik problematis, juga disampaikan dengan pola homeostatika yaitu keselarasan antara akal kecerdasan dan perasaan yang melahirkan perilaku akhlakul karimah dalam kehidupan berbangsa dan bernegara. Pola ini menuntut upaya lebih menekankan pada faktor kemampuan berfikir dan berperasaan moralis yang merentang ke arah Tuhannya, dari ke arah masyarakatnya, di mana iman dan taqwa menjadi rujukannya. (Arifin, 1991). ${ }^{4}$

Model penyampaian pendidikan agama seperti tersebut diatas, menuntut para pendidik agama, baik di keluarga, di sekolah maupun di masyarakat untuk bertindak secara sistematis, terprogram dan profesional. Tuntutan ini makin kuat tertuju pada para guru agama di sekolah, karena pendidikan agama di sekolah dianggap yang paling penting, sebab itu daya upaya peningkatan pendidikan agama, biasanya difokuskan pada pendidikan formal (Subiyanto, 1994). ${ }^{5}$

Pendidikan agama di sekolah, sebagaimana bidang studi yang lain, kurikulumnya telah tersusun dengan baik secara nasional dengan mengikuti sistem pengajaran PPSI. Maka dari itu, yang dipermasalahkan dalam penelitian ini bukan isi kurikulum pendidikan agama, melainkan bagaimana kurikulum itu dilaksanakan oleh guru agama di sekolah-sekolah di Kodia Malang ini.

\section{Perumusan Masalah}

Atas dasar itu maka masalahnya dapat dirumuskan sebagai berikut:

1. Bagaimana tehnik, strategi dan upaya guru agama dalam melaksanakan pendidikan agama di sekolah?

2. Bagaimana kondisi kontektual yang memberikan kekuatan sebagai pendorong atau penghambat pelaksanaan pendidikan agama di sekolah? 


\section{Tujuan Penelitian}

Berdasarkan rumusan masalah di atas, maka penelitian ini bertujuan untuk:

1. Mendiskripsikan pelaksanaan pendidikan agama di sekolah,

2. Menelusuri kondisi kontekstual yang memberikan kekuatan sebagai pendorong atau penghambat pelaksanaan pendidikan agama di sekolah.

\section{Batasan Konsep}

1. Pendidikan agama ialah salah satu bidang studi yang diajarkan di sekolah yang didalamnya berisi materi pelajaran tentang Al-Qur'an-Hadits, Aqidah - Akhlaq, Fiqh-Syari'ah, dan Sejarah Kebudayaan Islam.

2. Sekolah adalah lembaga pendidikan umum yang meliputi : Sekolah Dasar (SD) Sekolah Menengah Pertama (SMP) dan Sekolah Menengah Umum (SMU).

3. Guru Agama adalah mereka yang mengajarkan agama/mendidik agama di sekolah.

\section{Kegunaan Hasil Penelitian}

Hasil penelitian ini diharapkan berguna untuk:

1. Bahan supervise untuk meningkatkan kualitas profesionalisasi guru agama.

2. Masukan untuk menentukan pilihan dalam mengadakan pelatihan ketrampilan mengajar bagi.guru agama.

3. Mengatasi kelemahan sistem yang selama ini dihadapi oleh guru agama.

\section{Sistematika Laporan Penelitian}

Setelah pendahuluan ini, akan disajikan kajian teori yang berkenaan dengan pelaksanaan pendidikan agama di sekolah. Kemudian menyusul 
uraian tentang Metodologi Penelitian, yang memuat : Paradigma penelitian, desain penelitian, populasi dan sampel penelitian, metode pengumpulan data dan metode analitis data. Berikutnya disajikan hasil-hasil penelitian yang berupa penyajian dan analisis data yang telah dikumpulkan dalam penelitian ini. Kemudian diskusi hasil-hasil temuan penelitian. Akhimya laporan ini ditutup dengan kesimpulan dan saran.

\section{Kajian Teori}

Pendidikan agama sejak sebelum penjajahan Belanda sudah ada dan dilaksanakan di keluarga, langgar, masjid dan kemudian di Pondok Pesantren. Kedatangan penjajah Belanda yang memperkenalkan model sekolah, ditambah dengan gerakan pembaharuan yang dibawa oleh para ulama Indonesia yang belajar di Mekkah dan Mesir, maka mulai dicoba mengembangkan sistem pendidikan Madrasah di pondok-pondok Pesantren. Malah sudah dirintis juga pendidikan agama diberikan di sekolah umum, meskipun belum dimasukkan secara formal dalam kurikulum.

Setelah kita merdeka, maka pendidikan agama mulai dimasukkan ke dalam kurikulum sekolah umum, hanya sifatnya masih sukarela. Berdasarkan peraturan bersama antara Menteri Agama dan Menteri Pendidikan dan Pengajaran yang dikeluarkan bulan Desember 1946, menyatakan bahwa pendidikan agama diberikan mulai kelas IV sampai dengan kelas VI SR (sekarang SD). Menurut pasal 20 ayat 1, Undang undang No.4 tahun 1950 tentang Dasar-dasar Pendidikan dan Pengajaran di Sekolah, menyebutkan bahwa dalam sekolah-sekolah Negeri diadakan pelajaran agama; orang tua murid menetapkan apakah anaknya akan mengikutipelajaran tersebut.

Perkembangan lebih lanjut, Tap MPRS No.IVI960 Bab H pasal 2.ayat 3 menyebutkan bahwa: pendidikan agama menjadi mata pelajaran di sekolahsekolah umum, mulai sekolah rendah (dasar) sampai universitas, dengan pengertian bahwa murid berhak tidak ikut sertadalam pendidikan agama, jika wali murid/murid dewasa menyatakan keberatan. Setelah G 30 S/ PKI, maka pemikiran tentang pendidikan agama di sekolah terus 
dikembangkan, sehingga Tap MPR RI tahun 1973, 1983, 1989 dan 1993 danUUSPN mewajibkan pendidikan agama masuk dalam kurikulum sekolah.

Menurut Mochtar Buchari, praktek pendidikan agama di Indonesia itu ada 4 macam, yaitu, pertama: pendidikan agama yang dilaksanakan secara tradisional di Pondok Pesantren, kedua : Pendidikan agama yang dilaksanakan di madrasah, ketiga : pendidikan agama yang dilaksanakan di lembaga-lembaga pendidikan Islam yạng bersifat umum dan keempat : pendidikan agama Islam yang dilaksanakan oleh lembaga pendidikan umum sebagai suatu mata pelajaran, bidang studi atau mata kuliah saja. ${ }^{6}$

Pendidikan agama yang dilaksanakan di sekolah umum, (yang menjadi pusat kajian dalam penelitian ini), sebagai bidang studi, juga mengikuti sistim pengajaran seperti bidang studi lain. Kurikulum pendidikan agama disusun dalam format terinci sebagaimana terlihat dalam GBPP PAI sesuai dengan jenjang pendidikan yang bersangkutan. GBPP tersebut memuat antara lain : pengertian, tujuan, ruang lingkup materi, fungsi, pendekatan, metode, media dan evaluasi. Untuk itu guru agama dituntut untuk benar-benar mampu menterjemahkan isi kurikulum sebagai cerminan cita-cita ideal dalam pelaksanaan pendidikan agama di Indonesia. Kemampuan ini mencakup kemampuan merancang pembelajaran yakni membuat Satpel dan kemampuan PBMnya yakni kemampuan menyampaikan pelajaran di kelas. Oleh karena pendidikan agama harus menyentuh aspek kognitif, afektif dan psikomotorik secara seimbang, maka kegiatan intra-kurikuler, harus dilengkapi kegiatan kokurikuler dan extra kulikuler. Namun umumnya bobot evaluasi yang paling tinggi diletakkan pada intra kurikuler, sedangko-kurikuler dan extra kurikuler digunakan sebagai pelengkap dalam evaluasi hasil pendidikan agama. Guru dituntut untuk merancang kesemuanya itu dengan baik. Mengidentifikasi kemampuan-kemampuan guru agama dalam merekayasa pelaksanaan pendidikan agama inilah yang menjadi tekanan dalam penelitian ini.

Mengenai faktor penunjang dan penghambat terhadap pelaksanaan pendidikan agama, initerkait dengan komponen-komponen pendidikan, baik yang berasal dari diri pendidik, anak didik, alat dan masyarakat sekitar. 


\section{Metode Penelitian Paradigma dan Desain Penelitian}

Paradigma diartikan sebagai kumpulan longgar tentang asumsi yang secara logis dianut bersama, konsep atau proposisi yang mengarahkan cara berfikir dan cara penelitian.' Paradigma penelitian diperlukan untuk menentukan cara dan arah pelaksanaan penelitian sehingga terdapat konsistensi pemikiran, pembahasan dan pelaporannya. ${ }^{8}$ Ritzer membuat bagan tentang tingkat-tingkat utama mengenai realitas sosial, dimana ada 4 kuadran yaitu kuadran Macroscopic obyektif dan subyektif dan kwadran microscopic obyektif dan subyektif. Kedudukan pelaksanaan pendidikan berada pada kwadran ketiga yaitu kuadran microscopicobyektif. ${ }^{9}$ Hal ini akan nampak jelas dalam bagan yang diadaptasi dari paradigma Ritzer dibawah ini.

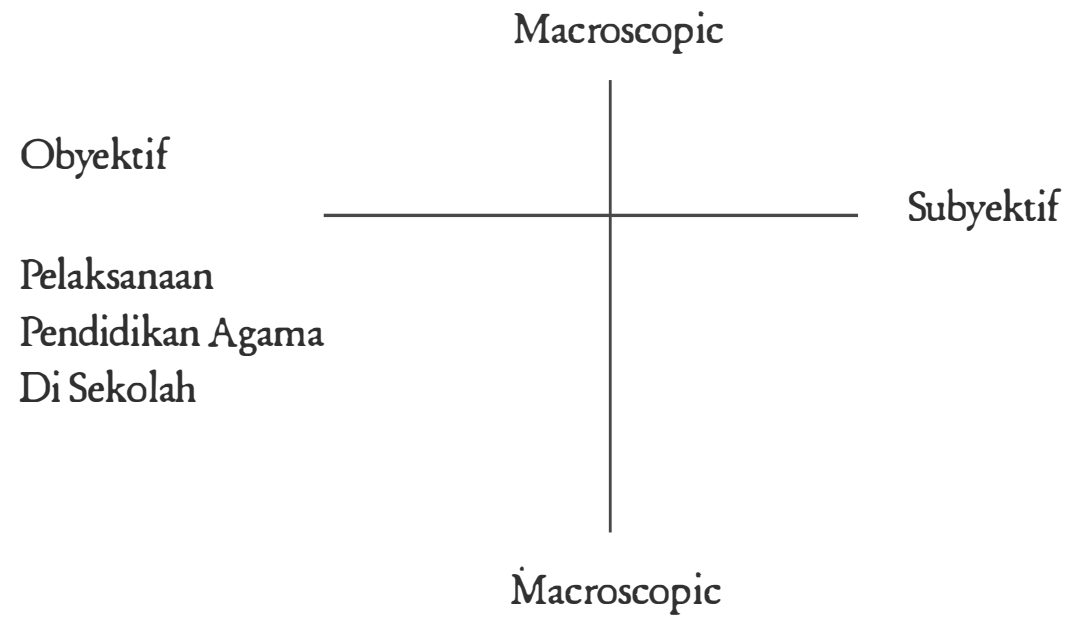

Melihat posisi pelaksanaan pendidikan agama di sekolah terletak pada kwadran ke-3 yakni kwadran microscopic obyektif, maka desain penelitian yang tepat ialah desain deskriptif kuantitatif, meskipun tidak menutup kemungkinan penggunaan analisis deskriptif kualitatif, bila data yang diperoleh berupa data kualitatif, sehingga keduanya bisa saling melengkapi. 


\section{Populasi dan Sampel Penelitian}

Populasi dari penelitian ini adalah seluruh sekolah umum di Kodia Malang, baik yang berstatus negeri maupun swasta. Mengingat keterbatasan tenaga, waktu dan dana, maka tidak semua unit populasi diteliti. Penelitian ini akan menggunakan sampel yang ditarik secara purposif. Dasar pikirannya ialah, bahwa 1). Sekolah-sekolah umum di Kodia Malang mempunyai prestasi yang cukup menggembirakan, dari hasil pembinaan yang terus menerus, 2) Kodia Malang sebagai kota pendidikan, cukup memberi motivasi tiap lembaga pendidikan untuk selalu berbenah diri dan 3) Status negeri swasta tidak lagi menggambarkan kelas satu dan kelas dua, akan tetapi sudah sebagai mitra yang berkedudukan yang sama. Dengan pertimbangan ini, maka kondisi sekolah umum di Kodia Malang boleh dikatakan relatif homogen, sehingga dalam pengambilan sampel tidak menjadi masalah metodologis. Atas dasar pertimbangan ini, sekaligus bisa mewakili semua jenjang pendidikan, maka ditunjuk sampel sebanyak 6 sekolah umum negeri dan swasta dengan rincian 4 unit sekolah jenjang pendidikandasar dan 2 unit sekolah jenjang pendidikan menengah. Keenam unit sekolah tersebut ialah : 1) SDN 3, 2) SMPN 8, 3) SMPN 9, 4) SMP Muhammadiyah 17, 5) SMU 4,6) SMU 7. Adapun responden penelitian ini terdiri semua kepala sekolah, semua guru agama dan murid yang seluruhnya berjumlah 436 orang dengan rincian : 6 kepala sekolah, 34 guru agama, 396 murid SD, SMP dan SMU.

Perlu dijelaskan penunjukan sampel murid dan guru yang diobservasi kemampuan melaksanakan proses belajar mengajar di kelas, digunakan tehnik accidental sampling, yakni mengambil kelas yang pada saat observasi dilakukan sedang diajar oleh guru agama.

Adapun metode pengumpulan data yang digunakan adalah: 1) Metode observasi, khusus digunakan untuk mengamati proses belajar mengajar guru agama di kelas. Metode wawancara, digunakan untuk mengungkapkan keterlibatan kepala sekolah, guru umum dan guru agama dalam kegiatan agama di sekolah. Metode angket diberikan pada guru agama dan murid, untuk mengungkap data PBM dan upayaguru agama dalam melaksanakan pendidikan agama dan tanggapan murid terhadap pendidikan agama. Metode 
dokumenter digunakan untuk menilai kemampuan guru dalam menyusun satpel pendidikan agama.

Data yang telah dikumpulkan dianalisis sesuai dengan bentuk data. Untuk data kuantitatif dianalisis dengan tehnik statistik, sedang untuk data kualitatif digunakan tehnik analisis deskriptif kualitatif yakni dengan reflectif chinking.

Untuk data hasil angket, digunakan tehnik prosentase dengan rumus

$$
P=\frac{f}{N} \times 100 \%
$$

Untuk data hasil observasi untuk menetapkan nilai masing-masing guru digunakan skor individual, dengan rumus:

$$
\frac{\text { Skor nyata }}{\text { Skor ideal }} \times 100
$$

Untuk memperoleh kesimpulan nilai dari hasil observasi dan angket masing-masing guru digunakan rumus:

$$
\mathrm{M}=\frac{}{\mathrm{N}}
$$

Selanjutnya M ini digunakan untuk menentukan kualifikasi prestasi masing-masing guru dengan kriteria sebagai berikut :

$\begin{array}{ll}\text { Nilai M } & \text { Kualifikasi } \\ 85-100 & \text { sangat baik } \\ 70-84 & \text { baik } \\ 60-69 & \text { cukup } \\ 50-59 & \text { kurang } \\ 0-49 & \text { sangat kurang }\end{array}$

Sedangkan untuk menghilangkan faktor subyektifitas dari responden dan untuk menetapkan peringkat prestasi dari masing masing sekolah, 
digunakan uji, nilai standard z skor dengan rumus sebagai berikut:

$$
\mathrm{X}-\mathrm{M}
$$

$\mathbf{z}=$

$\mathrm{SD}$

Penyajian dan analisis data Kondisi Guru Agama

Untuk mengetahui bagaimana kondisi guru agama akan disajikan tentang : Tingkat pendidikan guru, pengalaman mengajar guru, punya tidaknya kerja sampingan, terpenuhi tidaknyakebutuhan pokoknya dan disiplin masuk kelas. Dari angket diperoleh data seperti dalam tabel berikut:

TABEL 1

KONDISI GURU AGAMA

\begin{tabular}{|l|l|r|r|r|}
\hline \multicolumn{1}{|c|}{ Kondisi } & Alternatif jawaban & N & f & $\%$ \\
\hline Tingkat Pendidikan & SLTA/PGA & & 6 & 17,65 \\
& Sarmud/Diploma & 34 & 11 & 32,35 \\
& Sarjana & & 17 & 50 \\
\hline Pengalaman Mengajar & 1-5 Tahun & & 16 & 47,06 \\
& 6-10 Tahun & 34 & 10 & 29,41 \\
& 11-15 Tahun & & 6 & 17,65 \\
& 15 keatas & & & 5,88 \\
\hline Sampingan Mengajar & Ya & 34 & 8 & 23,53 \\
& Tidak & 34 & 26 & 76,47 \\
\hline Pemenuhan kebutuhan & Terpenuhi & 34 & 26 & 76,47 \\
pokok sehari-hari & Belum & & 8 & 23,53 \\
\hline Disiplin waktu mengajar & Tepat waktu & & 27 & 79,41 \\
& Kadang-kadang & 34 & 5 & 14,71 \\
& terlambat & & & \\
& Sering terlambat & & 2 & 5,88 \\
\hline
\end{tabular}


Berdasarkan data di atas, maka dapat dikemukakan bahwa:

1. Bahwa sebagian besar guru agama Islam di sekolah yang dijadikan sampel penelitian berijasah sarjana (50\%), kemudian sarjana muda atau diploma $(32,35 \%)$, dan hanya sebagian kecil saja yang masih berijasah PGA $(17,65 \%)$.

2. Bahwa sebagian besar guru agama Islam tersebut masih berpengalaman mengajar kurang dari 10 tahun (76.47\%), dan hanya sebagian kecil saja berpengalaman mengajar di atas 15 tahun (5,88\%).

3. Guru agama yang merangkap mengajar di tempat lain juga hanya sedikit (23,53\%), dan alasan merangkap mengajar di lembaga lain ini, selain untuk menambah income, juga karena ingin mengembangkan ilmu dan ada juga karena lembaga lain tersebut perlu bantuan.

4. Dengan profesi mengajar, guru agama Islam sudah merasa terpenuhi kebutuhan pokok sehari-harinya, meskipun sebagian kecil mengatakan belum $(23,53 \%)$.

5. Guru agama Islam dalam melaksanakan tugas mengajar sebagian besar sudah menetapi disiplin waktu dalam mengajar, hanya sebagian kecil saja (20,59\%) yang sering dan kadang-kadang terlambat, dengan alasan jalan macet, karena mereka harus naik mikrolet.

\section{Kondisi sekolah}

Ada tiga hal yang perlu diungkapkan berkaitan dengan aktifitas guru agama di sekolah yakni, kewajiban datang ke sekolah meskipun tidak mengajar, tersedia tidaknya sarana ibadah di sekolah dan kegiatan keagamaan di sekolah. Data ketiga hal tersebut disajikan dalam tabel di bawah ini: 
TABEL 2

KONDISI SEKOLAH

\begin{tabular}{|l|l|r|r|l|}
\hline \multicolumn{1}{|c|}{ Kondisi sekolah } & Alternatif jawaban & N & F & $\%$ \\
\hline Kewajiban datang di sekolah & Tiap hari datang & 34 & 25 & 73,53 \\
& Kadang-kadang & & 9 & 26,47 \\
\hline Keadaan sarana mengajar & Punya & 6 & 4 & 66,67 \\
& Tidakpunya & & 2 & 33,33 \\
\hline Kegiatan keagamaan & Murid diwajibkan iku & 34 & 32 & 94,12 \\
di sekolah & Kadang-kadang & 2 & 5,88 & \\
\hline
\end{tabular}

Dari tabel di atas dapat dikemukakan, bahwa:

1. Sekolah di mana guru agama Islam mengajar, sebagian besar mewajibkan guru agama datang ke sekolah setiap hari, meskipun mereka tidak mengajar pada hari itu (73,53\%), dan hanya $26,47 \%$ saja yang sekolahnya tidak mewajibkan guru agama dätang setiap hari.

2. Sekolah-sekolah yang telah mempunyai sarana ibadah, telah digunakan untuk kegiatan keagamaan secara terprogram dan untuk shalat lima waktu. Dari hasil interviu dan observasi di lapangan, termyata, guru agama telah mewajibkan murid untuk shalat wajib secara bejama' ah yaitu shalat dhuhur. Karena daya tampung tempat ibadah di sekolah relatif kecil, biasanya diatur secara bergilir per kelas. Perlu dijelaskan umumnya tempat ibadah di sekolah (mushala) berada di belakang sehingga masyarakar sekitar tidak bisa ikut meramaikan mushala tersebut.

3. Semua guru agama Islam telah mewajibkan murid-murid untuk selalu ikut kegiatan keagamaan di sekolah, seperti PHBI, pesantren kilat dll dan bagi siswa yang tidak mengikuti diberi sanksi antara berupa: a) mengerjakan tugas khusus, b) pengurangan nilai, c) membuat paper d) menyalin ayat -ayat $\mathrm{Al}-\mathrm{Q} u \mathrm{r}^{\prime}$ an yang ditentukan guru, e) membersihkan kelas atau tempat ibadah, $f$ ) memanggil orang tuanya untuk diberi penjelasan tentang anaknya, g) diberi peringatan secara lisan atau tertulis. 


\section{Kegiatan Pembelajaran Pendidikan Agama Islam di Sekolah}

Para guru agama berpendapat bahwa tujuan pendidikan agama adalah (1) membentuk manusia beriman dan bertaqwa, 2) membentuk manusia yang cerdas, trampil, dan religius, (3) membentuk manusia yang intelek, dan (4) membentuk manusia yang berakhlaq mulia. Untuk mencapai tujuan tersebut, semua guru agama berusaha mengajarkan pendidikan agama dengan menekankan pada askep kognitif, afektif dan psikomotorik dengan secara seimbang dan terintegrasi. Untuk mengetahui bagaimana proses pembelajaran pendidikan agama ini, dibawah ini disajikan tabel berikut:

TABEL 3

KEGIATAN PEMBELAJARAN PENDIDIKAN AGAMA ISLAM

\begin{tabular}{|l|l|c|c|l|}
\hline Aspek-aspek kegiatan & \multicolumn{1}{|c|}{ Alternatif jawaban } & N & F & $\%$ \\
\hline Sasaran & Domain kognitif & & 3 & 8,82 \\
& $\begin{array}{l}\text { Domain afektif } \\
\text { Domain psikomotrik }\end{array}$ & 34 & 27 & 79,41 \\
& & & 22,76 \\
\hline Pelajaran penunjang & Sering diberikan & & 24 & 70,58 \\
& Kadang-kadang & 34 & 5 & 14,71 \\
& Tidak pernah & & 5 & 14,71 \\
\hline
\end{tabular}

Dari tabel tersebut nampak bahwa guru agama telah memilih domain afektif menjadi sasaran garapan yang ditekankan dalam PBM pendidikan agama. Hal ini dipandang tepat, karena dalam hidup beragama sikap dan penghayatan beragama adalah sangat penting melebihi pemahaman dan ketrampilan melaksanakan. Untuk memperkaya wawasan anak didik, guru agama juga sering memberi pelajaran penunjang yang tidak tercantum dalam kurikulum. 
Adapun mengenai metode yang digunakan ialah metode ceramah, tanyajawab, metode drill, demonstrasi dan kerja kelompok. Sedangkan media yang digunakan ialah media yang ada dan tidak terprogram/terdesain. Untuk ukuran keberhasilan pendidikan agama, sebagian besar guru agama menyebut perobahan tingkah laku murid.

Berpedoman pada ukuran keberhasilan di atas, sebagian besar guru $(55,88)$ mengatakan bahwa pendidikan agama yang dilaksanakan cukup berhasil. Hal ini ditunjang oleh pemyataan murid, yang menyatakan bahwa $60,88 \%$ aktif menjalankan shalat lima waktu, 37,12\% murid menyatakan kadang-kadang shalat dan hanya sebagian kecil saja (2,02\%) murid yang menyatakan tidak shalat.

Keaktifan shalat dari murid ini, nampak dipengaruhi oleh kondisi orang tua mereka. Temyata $78,03 \%$ orang tua murid juga menjalankan shalat secara aktif, 20,20\% menyatakan kadang-kadang dan yang tidak shalat hanya $1,17 \%$ saja.

\section{Kemampuan guru agama Islam dalam merancang pembelajaran (Satpel)}

Data tentang hal ini diperoleh dari memeriksa Satpel yang dibuat oleh guru agama yang pada waktu guru agama sedang mengajar dan peneliti meminjam Satpel yang dibuatnya. Dari 11 guru yang ditemui, ternyata satu orang guru yang tidak membuat Satpel. Tehnik penilaian kemampuan guru di bidang ini, peneliti menggunakan "Alat Penilaian Kemampuan Guru Menyusun Rencana Pengajaran" hasil Tim dari IKIP Malang. ${ }^{10}$

Ada 6 komponen yang dinilai yaitu meliputi : Rumusan TIK, pengorganisasian bahan pengajaran, pengelolaan kegiatan belajar mengajar, alat sarana, sumber pengajaran, penilaian prestasi siswa. Masing-masing komponen ditentukan indikatornya dan penilaiannya menggunakan skala deskriptor masing-masing. Skala deskriptor disusun berskala lima dari yang tidak sesuai dengan ketentuan dalam kurikulum sampai yang paling cocok dengan yang dikehendaki kurikulum. 
Untuk jelasnya komponen beserta indikatomya disajikan di bawah 1n!:

1. Perumusan TIK

1) Menilai perumusan TIK yang akan dicapai

2. Merencanakan pengorganisasian bahan pengajaran

1) Menilai penggunaan bahan pengajaran yang tercantum dalam kurikulum sekolah

2) Menilai penentuan bahạn pengajaran bidang studi

3) Menilai penyusunan bahan pengajaran dalam berbagai jenjang kemampuan

3. Merencanakan Pengelolaan Kegiatan Belajar mengajar

1) Menilai penentuan pendekatan yang digunakan

2) Menilai penentuan metode mengajar yang dipakai

3) Menilai langkah-langkah mengajar yang akan ditempuh

4) Menilai cara-cara memotivasi murid dalam kegiatan belajar mengajar

4. Merencanakan penggunaan alat/media dan sumber pengajaran

1) Menilai penggunaan media pengajaran yang dipakai

2) Menilai penggunaan sumber/peralatan ibadah dalam rencana pengajaran

5. Merencanakan sumber pengajaran

1) Menilai buku pegangan yang dipakai guru

2) Menilai buku pegangan yang dipakai murid

3) Pemakaian LKS

6. Merencanakan penilaian prestasi siswa

1) Menilai bentuk penilaian yang tercantumdalam Satpel

2) Menilai prosedur yang dilalui dalam menilai prestasi murid

3) Menilai pembuatan alat penilaian

Masing-masing indikator diberi skor menurut skala deskriptor yaitu 
skala lima, dari tidak sesuai skor (skor 1) sampai yang paling cocok (skor 5) dengan yang dikehendaki kurikulum. Dengan tehnik skoting ini masing masing guru memperoleh skor, minimal 16 dan maksimal 90. Dari skor ini dapat ditentukan skor rata-rata kemampuan tiap indikator, nilai kemampuan guru, kualitas prestasi guru, dan tingkat prestasi.

Rekapitulasi kemampuan guru dalam merencanakan Satpel disajikan dalam tabel sebagai berikut :

TABEL 4

REKAPITULASI KEMAMPUAN GURU DALAM
MERENCANAKAN SATPEL

\begin{tabular}{|c|l|l|l|c|c|l|c|}
\hline No. & Skor & $\begin{array}{c}\text { Mean } \\
\text { ndikator }\end{array}$ & Nilai & $\begin{array}{c}\text { Mean } \\
\text { Skor }\end{array}$ & $\begin{array}{c}\text { Z } \\
\text { Sekolah }\end{array}$ & $\begin{array}{c}\text { Kualitas } \\
\text { Prestasi }\end{array}$ & $\begin{array}{c}\text { Tingkat Prst. } \\
\text { Sekolah }\end{array}$ \\
\hline 1. & 61 & 3,81 & 76,25 & 69,20 & $-1,97$ & Baik & IV \\
2. & 62 & 3,88 & 77,50 &,-- & $-1,97$ & Baik & IV \\
3. & 71 & 4,43 & 88,75 &,-- & 0,43 & Sangat Baik & II \\
4. & 71 & 4,43 & 88,75 &,-- & 0,43 & Sangat Baik & II \\
5. & 70 & 4,37 & 87,50 &,-- & 0,43 & Sangat Baik & II \\
6. & 70 & 4,37 & 87,50 &,-- & 0,19 & Sangat Baik & III \\
7. & 73 & 4,56 & 91,25 &,-- & 0,67 & Sangat Baik & I \\
8. & 72 & 4,50 & 90 &,-- & 0,67 & Sangat Baik & I \\
9. & 72 & 4,50 & 90 &,-- & 0,67 & Sangat Baik & I \\
10. & 73 & 4,56 & 91,25 &,-- & 0,67 & Sangat Baik & I \\
\hline
\end{tabular}

Berdasarkan tabel ini, maka dapat dijelaskan bahwa:

1. Dari sebelas guru agama yang diteliti, temyata hanya seorang yang tidak membuat Satpel. Maka dari itu analisis kemampuan guru dalam membuat Satpel respondennya 10 orang guru agama Islam.

2. Dari 10 orang guru agama Islam yang membuat Satpel, sebagian besar (80\%) mencapai kualitas prestasisangat baik, dan yang $20 \%$ sisanya itupun masih mencapai kualitas prestasi baik. 
3. Berdasarkan $z$ skor sekolahnya, maka urutan tingkat prestasi dalam menyusun rencana pembelajaran (Satpel) adalah sebagai berikut:

a) Peringkat I adalah SMU.4 dan SMU 7

b) Peringkat II adalah SMP 9

c) Peringkat III adalah SMP Muhammadiyah 17

d) Peringkat IV adalah SMP 8 dan SDN 3.

\section{Kemampuan guru dalam melaksanakan Proses Belajar Mengajar Pendidikan Agama di kelas}

Data ini diperoleh melalui observasi sewaktu guru yang bersangkutan mengajar di kelas. Guru yang diobservasi sebanyak 11 orang guru agama. Ada 7 komponen yang dinilai dengan 24 indikator, yang masing-masing indikator dinilai dengan deskriptor yang menggunakan skala lima yaitu dari pelaksanaan mengajar yang tidak sesuai sampai yang paling sesuai dengan Satpel.

Komponen dan indikator dimaksud adalah sebagai berikut :

1. Penggunaan metode, media, dan bagian pembelajaran yang sesuai dengan tujuan pembelajaran.

1) Menggunakan metode mengajar yang sesuai dengan tujuan, siswa, lingkungan dan perubahan situasi.

2) Menggunakan media yang ada dan digunakan sesuai dengan tujuan pembelajaran.

3) Menggunakan dengan tepat bahan pembelajaran yang sesuai dengan tujuan pembelajaran.

2. Berkomunikasi dengan siswa.

1) Memberi petunjuk dan penjelasan yang berkaitan dengan isi pelajaran

2) Mengklarifikasi petunjuk dan penjelasan bila siswa salah mengerti.

3) Menggunakan respon dan pertanyaan siswa dalam pengajaran.

4) Menggunakan ekspresi lisan atau tertulis yang dapat ditangkap oleh 
semua siswa.

5) Menutup pelajaran

3. Mendemonstrasikan khasanah metode mengajar

1) Mengimplementasikan kegiatan belajar mengajar dengan urutan yang logis.

2) Mendemonstrasikan kemampuan mengajar dengan menggunakan berbagai metode

3) Mendemonstrasikan kemampuan mengajar secara individual atau secara kelompok.

4. Mendorong dan melibatkan siswa dalam pengajaran

1) Menggunakan prosedur yang melibatkan siswa pada awal pengajaran/ membuka pelajaran

2) Memberi kesempatan pada siswa untuk berpartisipasi

3) Memelihara keterlibatan siswa dalam pelajaran

4) Menguatkan upaya siswa untuk memelihara keterlibatan/ reinforcemental.

5. Mendemonstrasikan penguasaan mata pelajaran dan relevansinya.

1) Membantu siswa dalam mengenal maksud dan pentingnya topik

2) Mendemonstrasikan penguasaan pengetahuan dalam mata pelajaran

6. Mengorganisasi waktu, ruang, bahan dan perlengkapan pengajaran

1) Melaksanakan tugas-tugas rutin secara disiplin

2) Menggunakan waktu pengajaran siswa secara efisien

3) Menyediakan lingkungan belajar yang menarik dan teratur

4) Menyediakan bahan dan perlengkapan pengajaran

7. Mengadakan evaluasi pencapaian siswa dalam proses belajar mengajar

1) Melakukan penilaian selama proses belajar mengajar berlangsung

2) Mendemonstrasikan pelaksanaan penilaian baik dengan lisan, tertulis, observasi maupun demontrasi.

3) Menafsirkan hasil penilaian dalam proses belajar mengajar yang telah 
ditentukan.

Dengan tehnik skoring pada setiap indikator dengan menggunakan deskriptor skala lima maka masing-masing guru mempunyai skor berkisar antara skor minimal 24 dan maksimal 124. Dari skor masing-masing guru ini, dapat dihitung Mean Indikator, Nilai Prestasi Guru, Z Skor Sekolah, Kualitas Prestasi Sekolah dan Peringkat Prestasi Sekolah.

Hasil perhitungan tersebut dapat dilihat dalam tabel sebagai berikut:

\begin{tabular}{|l|l|c|c|c|c|l|c|}
\hline No. & Skon & $\begin{array}{c}\text { Mean } \\
\text { ndikator }\end{array}$ & Nilai & $\begin{array}{c}\text { Mean } \\
\text { Skor }\end{array}$ & $\begin{array}{c}\text { Z } \\
\text { Sekolah }\end{array}$ & $\begin{array}{c}\text { Kualitas } \\
\text { Prestasi }\end{array}$ & $\begin{array}{c}\text { Tingkat Prst } \\
\text { Sekolah }\end{array}$ \\
\hline 1. & 88 & 3,67 & 73,33 & 100,83 & $-2,14$ & Baik & IV \\
2. & 100 & 4,17 & 83,33 &,-- & 0,19 & Baik & III \\
3. & 104 & 4,33 & 86,67 &,-- & 0,19 & Sangat Baik & III \\
4. & 101 & 4,20 & 84,16 &,-- & 0,19 & Baik & III \\
5. & 103 & 4,29 & 85,83 &,-- & 0,19 & Sangat Baik & III \\
6. & 103 & 4,29 & 85,83 &,-- & 0,19 & Sangat Baik - & III \\
7. & 103 & 4,29 & 85,83 &,--- & 0,36 & Sangat Baik & I \\
8. & 108 & 4,50 & 90 &,-- & 1,03 & Sangat Baik & I \\
9. & 106 & 4,40 & 88,33 &,-- & 1,04 & Sangat Baik & II \\
10. & 105 & 4,37 & 87,50 &,-- & 0,36 & Sangat Baik & II \\
11. & 102 & 4,25 & 85 &,-- & 0,36 & Sangat Baik & II \\
\hline
\end{tabular}

Berdasarkan tabel ini, maka dapat dijelaskan bahwa:

1. Dari 11 orang guru agama Islam yang mengajar di sekolah umum, ternyata $72,73 \%$ mencapai kualitas prestasi yang sangat baik dalam melaksanakan proses belajar mengajar di kelas, dan 27,27\% sisanya masih berkualitas baik.

2. Atas dasar kualitas kemampuan melaksanakan proses belajar mengajar tersebut maka peringkat prestasi sekolah berturut-turut sebagai berikut

1) Peringkat I adalah SMU 4

2) Peringkat II adalah SMU 7 dan SMP Muhammadiyah 17 
3) Peringkat-III adalah SMP8 dan SMP9

4) Peringkat $I V$ adalah SD 3

\section{Keterlibatan guru bidang studi lain dalam pembelajaran pendidikan agama}

Dari data yang terkumpul diketahui bahwa dalam melaksanakan kegiatan keagamaan guru agama juga melibatkan guru bidang studi lain, seperti guru ekonomi, fisika, kimia, biologi sejarah dsb untuk berpartisipasi dalam kegiatan keagamaan di sekolah

Berikut ini disajikan tabel tentang bagaimana keterlibatan guru lain dalam kegiatan keagamaan, baik menurut guru agama maupun murid.

TABEL 6

TENTANG KETERLIBATAN GURU UMUM DALAM KEGIATAN KEAGAMAAN

\begin{tabular}{|c|c|c|c|c|}
\hline Jenis data/kegiatan & Alternatif jawaban & $\mathrm{N}$ & $\mathrm{F}$ & $\%$ \\
\hline $\begin{array}{l}\text { 1. Upaya guru agama meli- } \\
\text { batkan guru umum }\end{array}$ & $\begin{array}{l}\text { Selalu melibatkan guru } \\
\text { umum } \\
\text { Kadang-kadang }\end{array}$ & 34 & $\begin{array}{r}30 \\
4\end{array}$ & $\begin{array}{l}88,24 \\
11,76\end{array}$ \\
\hline 2. Kuali & $\begin{array}{l}\text { Sangat baik } \\
\text { Biasa-biasa saja }\end{array}$ & $\begin{array}{l}34 \\
11\end{array}$ & $\begin{array}{l}23 \\
32,35\end{array}$ & 67,65 \\
\hline $\begin{array}{l}\text { 3. Kegiatan dalam mena- } \\
\text { namkan agama pada murid }\end{array}$ & $\begin{array}{l}\text { Sering bekerjasama } \\
\text { Kadang-kadang }\end{array}$ & 34 & $\begin{array}{l}27 \\
7\end{array}$ & $\begin{array}{l}79,41 \\
20,59\end{array}$ \\
\hline $\begin{array}{l}\text { 4. Pernyataan murid tentang } \\
\text { guru umum terlibat dalam } \\
\text { kegiatan }\end{array}$ & $\begin{array}{l}\text { Guru umum sering terlibat } \\
\text { Kadang-kadang } \\
\text { Tidak pernah }\end{array}$ & 396 & $\begin{array}{r}327 \\
64 \\
27 \\
\end{array}$ & $\begin{array}{r}82,58 \\
16,16 \\
6,82\end{array}$ \\
\hline $\begin{array}{l}\text { 5. Guru umum menjadi da'i, } \\
\text { imam shalat }\end{array}$ & $\begin{array}{l}\text { Pernah/sering } \\
\text { Kadang-kadang } \\
\text { tidak pernah }\end{array}$ & 396 & $\begin{array}{r}273 \\
96 \\
27\end{array}$ & $\begin{array}{r}68,94 \\
24,24 \\
6,82\end{array}$ \\
\hline $\begin{array}{l}\text { 6. Keteladanan guru umum } \\
\text { dalam menjalankan agama }\end{array}$ & $\begin{array}{l}\text { Mengagumi } \\
\text { tidak/biasa }\end{array}$ & 396 & $\begin{array}{r}346 \\
50\end{array}$ & $\begin{array}{l}87,37 \\
12,67\end{array}$ \\
\hline
\end{tabular}

Ulul Albab, Vol. 3 No. 1, 2001 
Berdasarkan data diatas, ternyata guru agama telah berusaha untuk melibatkan guru umum dalam kegiatan agama di sekolah, baik dalam bentuk partisipasi maupun kerjasama dalam penanaman nilai agama pada murid. Dari wawancara diketahui, bentuk-bentuk kerjasama antara guru agama dan guru umum itu meliputi:

a. Memberikan masukan untuk menanamkan materi pelajaran agama kedalam materi pelajaran umum seperti : IPS, Fisika dan Biologi

b. Bekerjasama untuk mengawasi tingkah laku siswa dalam kehidupan seharihari di sekolah

c. Mengadakan PHBI

d Mengadakan pesantren kilat

e. Mengadakan Pondok Romadlan

f. Kegiatan shalat berjamaah

g Melibatkan guru bidang studi umum dalam kegiatan khotbah Jum'ah dan penceramah agama

h. Menangani zakat fitrah di sekolah

1. Menjadikan imam shalat jamaah

Dengan keterlibatan guru bidang studi umum dalam kegiatan agama di sekolah ternyata menimbulkan rasa kagum pada diri siswa dan sekaligus meneladani pengamalan guru umum tersebut.

\section{Faktor penunjang pelaksanaan pendidikan agama di sekolah}

Faktor penunjang yang menonjol adalah antusiasnya siswa dalam menerima pendidikan agama, adanya macam-macam kegiatan keagamaan di sekolah dan dukungan dari kepala sekolah.

Bentuk-bentuk kegiatan yang menunjang pendidikan agama di sekolah ialah :

a. Peringatan Hari Besar Islam (PHBI) 

b. Badan Da'wah Islam
c. Pesantren kilat
d. Latihan Kader Dasar Muslim (LDKM)
e. Shalat berjamaah
f Pembelajaran Al-Qur'an dan kajian Islam
g. Pengajian rutin
h. Pondok Romadhon
1. Penambahan jam pelajaran
J. Praktek Khitabah
k. Bakti sosial ke Panti Asuhan

Adapun bentuk-bentuk dukungan kepala sekolah ialah antara lain
a. Selalu memberikan motivasi terhadap semua kegiatan keagamaan
b. Selalu mendampingi setiap ada kegiatan keagamaan
c. Menyediakan fasilitas pendukung
d. Memberikan dukungan dana kegiatan

\section{Faktor penghambat pelaksanaan pendidikan agama}

Mengenai faktor penghambat ini meliputi:

a. Masalah dana yang terbatas, sehingga tidak dapat mengembangkan kegiatan-kegiatan agama yang lebih kreatif

b. Sarana dan prasarana yang kurang memadai, sehingga sering sekedar memanfaatkan apa yang ada.

c. Siswa yang heterogen

d. Kadang-kadang ada sebagian siswa yang kurang semangat belajar agama, sehingga bisa mempengaruhi siswa yang lain.

e. Kurang mendukungnya lingkungan masyarakat

f. Informasi budaya luar yang tidak sesuai dengan kepribadian bangsa, 
yang nampak dari media elektronik.

g. Sebagian kecil siswa ada yang berekonomi lemah dan orang tuanya kurang aktif dalam hidup beragama.

\section{Diskusi Hasil Penelitian}

Guru agama, sebagai guru bidang studi, sebenarnya sudah terikat pada kurikulum dan GBPP PAI yang diberlakukan secara nasional. Mengingat begitu pentingnya fungsi agama dalam kehidupan manusia, sulitlah kiranya bila pendidikan agama tersebut hanya diajarkan dengan alokasi waktu 2 jam seminggu. Sedikitnya jam pelajaran agama ini pernah digunakan oleh para guru agama untuk menutupi kelemahan dan kurang berhasilnya pendidikan agama pada anak-anak. Menyadari alokasi waktu sulit dirubah, maka diupayakan bertagai cara untuk memfungsikan pendidikan agama sebagaimana yang diharapkan oleh undang -undang maupun GBHN, baik melalui peningkatan kualitas guru agama, penataran, NGBS, Supervisi dan sebagainya. Temuan penelitian ini menunjukkan hasil upaya tersebut.

Ada lima temuan yang menarik untuk didiskusikan.

\section{Kemampuan guru agama dalam mengelola pendidikan agama di kelas, baik dalam membuat Satpel maupun dalam PBM di kelas.}

Kualitas prestasi guru dalam membuat rencana pengajaran sangat baik dan baik. Demikian juga dalam hal melaksanakan pengajaran agama di kelas. Disamping itu, pemilihan pendekatan yang cukup tepat sebagai pengganti pendekatan indoktriner, dogmatis dan normatif, yang secara tradisional dilaksanakan selama ini. Pendekatan baru ini ialah pendekatan emperik problematis dan pendekatan pengalaman dan pembiasaan. Dalam hal ini guru agama berupaya untuk mengajak langsung anak didiknya mengalami, menghayati dan melakukan ajaran agama dalam kehidupan sehari-hari. 
2. Pemilihan sasaran dan metode pengajaran yang tepat

Sebagai bidang studi, materi pelajaran agama sudah dipatok dalam GBPP PAI dan harus diajarkan sesuai dengan alokasi waktu tertentu. Guru agama harus berfikir keras untuk menghabiskan materi GBPP. Untuk ini, pada umumnya metode ceramah yang menjadi favoritnya. Sasaran garapan yang pokokialah aspek kognitif. Ternyata guru-guru yang diteliti, mempunyai strategi yang lain. Bukan aspek kognitif atau psikomotorik yang diutamakan, melainkan aspek afektif. Guru agama telah menyadari bahwa pendidikan agama harus bisa menjadi kendali tingkah laku dan membentuk sikap agamis pada diri siswanya. Oleh karena itu guru agama telah memilih selain metode ceramah, juga metode tanya jawab, metode kerja kelompok, metode drill, dan metode demonstrasi.

\section{Guru agama tidak begitu terikat pada GBPP PAI}

Keterikatan yang kaku terhadap GBPP sering juga digunakan alat untuk menuduh merosotnya mutu pendidikan. Guru begitu dikungkung dan dituntut untuk menghabiskan materi GBPP tepat pada waktunya, akibatnya guru tidak sempat belajar dan memperluas wawasan keilmuannya. Tendensi yang muncul dalam diri guru ialah semangat menghabiskan materi GBPP tanpa peduli apakah anak didik bisa menerima dengan baik apa tidak. Dengan penuh kesadaran bahwa waktu tatap muka dimuka kelas sangat terbatas, maka guru agama berupaya dengan sekuat tenaga untuk mengadakan berbagai kegiatan dengan mengintensipkan pelaksanaan kegiatan ko-kurikuler dan ekstra kurikuler pendidikan agama. Berbagai kegiatan keagamaan telah berhasil dilaksanakan di sekolah seperti : shalat jama'ah, shalat Jum'at. ceramah agama, PHBI, pesantren kilat, pondok Romadhon dsb.

\section{Keterlibatan guru umum dalam kegiatan keagamaan di sekolah}

Peranan guru agama cukup besar dalam mengajak guru umum untuk berpartisipasi dalam berbagai kegiatan keagamaan. Keterlibatan guru umum ini, akan sangat membantu dalam menciptakan situasi kehidupan beragama 
di sekolah. Ternyata guru umum tidak hanya membantu, tetapi malah bisa tampil sebagai imam shalat, pemberi khotbah, penceramah agama dan terutama kesediaannya untuk ikut mengawasi tingkah laku murid seharihari di sekolah.

5. Dukungan kepala sekolah dalam kegiatan keagamaan di sekolah

Kepala sekolah sangat dominan peranannya dalam membina situasi keagamaan di sekolah. Inipun tidak lepas dari upaya guru agama dalam menjalin hubungan dan kerjasama dengan kepala sekolah. Ternyata guru agama yang diteliti, cukup berhasil dalam usaha ini, terbukti semua kepala sekolah membantu sepenuhnya upaya guru agama dalam melaksanakan pendidikan agama di sekolah, baik dengan selalu memotivasi perlunya kegiatan agama, meyediakan sarana/alat maupun mengusahakandana kegiatan.

\section{Kesimpulan}

1. Guru agama telah berusaha untuk memperbarui cara-cara melaksanakan pendidikan agama dengan mengadakan pendekatan baru yaitu pendekatan problematis emperik dan pendekatan pengalaman dan pembiasaan.

2. Ukuran keberhasilan lebih ditekankan pada perubahan tingkah laku agama anak, disamping pemahaman agama yang diajarkan.

3. Kualitas prestasi guru agama sangat baik dalam menyusun rencana pengajaran dan melaksanakan PBM di kelas.

4. Semua sekolah telah kondusif untuk pendidikan agama, karena semua kepala sekolah menjadi pendukung utama dalam kegiatan agama di sekolah.

6. Keterbatasan sarana, prasarana dan dana menjadi penghambat utamanya.

\section{Saran}

1. Penciptaan situasi kehidupan beragama di sekolah dengan melibatkan semua unsur sekolah, perlu dijadikan model pembinaan agama di sekolah. 
2. Keterlibatan guru bidang studi umum dalam menanamkan nilai-nilai agama lewat pelajaran umum, bisa ditingkatkan dan ditindak lanjuti.

\section{Notes:}

${ }^{1}$ GBHN.

${ }^{2} U U S P N$, Pasal 39 ayat 2.

${ }^{3}$ GBHN, Bab IV.

'Arifin. M, Kapita Selekta Pendidikan (Islam dan Umum), Oakarta: Bumi Aksara, 1991).

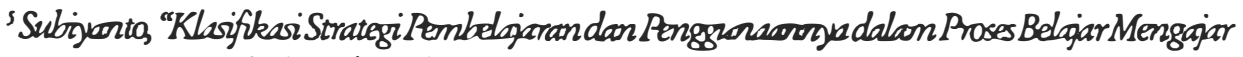
Agama", Makalah,(1994).

${ }^{6}$ Mubaimin, Konsep Pendidikan Islam, Sebuah Telaah Komponen Dasar Kurikulum, (Solo: Romadhon, 1991).

'Maleong, Lexy J., Metodologi Penelitian Kualitatif, Bardung: PT. Remaja Rosdakarya, 1993), hal. 8.

${ }^{8}$ Dimyati, M. Penelitian Kualitatif Untuk Ilmu - Imu Sosial, (Malang: FIP IKIP Malang, 1991).

${ }^{9}$ Ibid.

${ }^{10}$ Baharuddin Harahap dkk, IKIP Malang.

\section{Bibliography}

Ali, M., 1984, Penelitian Agama, Masalah dan Pemikiram Jakarta: Balitbang Depag RI. Arifin, M., 1991, Kapita Selekta Pendidikan (Islam dan Umum), Jakara: Bumi Aksara.

Dimyati, M., 1991, Penelitian Kualitatif Untuk Ilmu-Ilmu Sosial, Malang: FIP IKIP Malang.

DIRJEN BINBAGA., 1988, Kelembagaan Agama Islam di Indonesia, Jakarta: Dirjen Binbaga Islam Depag RI.

Dirjen Dikdasmen, 1993/1994, Kurikulum Pendidikan Dasar, Garis-Garis Besar Program Pengajaran (GBPP) Sekolah Dasar (SD), Mata Pelajaran Pendidikan Agama Islam, Jakarta: Dirjen Dikdasmen Depdikbud.

Depdikbud, 1993, Kurikulum Pendidikan Dasar, garis-Garis Besar Program Pengajaran (GBPP), Sekolab Lanjutan Tingkat Pertama (SLTP) Mata Pelajaran Pendidikan Agama Islam, Jakarta: Depdikbud.

Depdikbud, 1995, Kurikulum Sekolab Menengab Umum, Garis-Garis Besar Program 
Pengajaran (GBPP), Mata Pelajaran Pendidikan Agama Islam kelas 1, II, dan III, Jakarta: Depdikbud.

Kanwil Depag Jatim, 1982, Upaya Ptningkatan dan Ptmbiraan Perguruan Agama Islam Swasta; Surabaya: Bidang Pergurais.

Maleong, Lexy J, 1993, Metodologi Penelitian Kualitatif, Bandung. PT. Remaja Rosdakarya Kasiram, Moh., 1993, Kapita Selekta Pendidikan RI, Malang: UMM Press.

Muhaimin, 1991, Konsep Pendidikan Islam Sebuab Telaab Komponen Dasar Kurikulum, Solo: Romadhon.

Subiyanto, 1994, "Klasifikasi Strategi Pembelajaran dan Penggunaannya dalam Proses Belajar Mengajar Agama”, Makalah.

Hadi, Sutrisno, 1985, Statistik 1, Yogyakarta: Yayasan Penerbit Fak. PsikologiUGM.

Taher, Tarmidzi, 1996, "Prosepek Pendidikan Agama dan Pendidikan Keagamaan dalam Pembanģınan Pendidikan Nasional”, Makalah, Ujung Pandang, IKIP Ujung Pandang,

Zuhainini dkk, 1989, Sejarab Pendidikan Islam, Jakarta: Depag RI. 